\title{
Classification is the Method of System Problems Detection
}

\section{La clasificación es el método de detección de problemas del sistema}

DOI: $10.46932 /$ sfjdv2n3-006

Received in: March 1st, 2021

Accepted in: May 30th, 2021

Yury I. Lobanovsky

Ph. D., Fluid Mechanics, Thermodynamics, Auto Oscillations, System Engineering

IRKUT Corporation

68, Leningradsky prospect, Moscow, 125315, Russia

E-mail: streamphlow@gmail.com

\begin{abstract}
It has been shown by historical examples that neglect of the basic system principles in creation or development of complex systems led always to problems, failures and/or disasters. System engineering techniques were used to build a common classificatory of system problems. Its structure have been validated and verified. No projects, events or processes have been identified that could not find its natural place in this classificatory. Classification of system problems helps to better understand the reasons why complex systems are not able to perform the tasks assigned to them.
\end{abstract}

Keywords: problem, complex system, catastrophe, classification.

\section{RESUMEN}

Se ha demostrado con ejemplos históricos que el descuido de los principios básicos del sistema en la creación o el desarrollo de sistemas complejos conducía siempre a problemas, fallos y/o desastres. Se utilizaron técnicas de ingeniería de sistemas para construir un clasificador común de problemas de sistemas. Su estructura ha sido validada y verificada. No se ha identificado ningún proyecto, evento o proceso que no pueda encontrar su lugar natural en este clasificatorio. La clasificación de los problemas del sistema ayuda a comprender mejor las razones por las que los sistemas complejos no son capaces de realizar las tareas que se les asignan.

Palabras clave: problema, sistema complejo, catástrofe, clasificación.

\section{INTRODUCTION}

Improvement of methods for solving problems associated with the analysis of complex systems' behavior or their construction is an urgent task, solution of which can be useful in many types of human activity. System engineering has the most well-developed such methods, however, it practically does not systematize causes of failures that occurred earlier in the development of complex technical systems. But knowledge and understanding of causes of these failures and creation of conditions for their prevention in new projects can significantly increase degree of project success. 
Therefore, this work presents a general classifier of system problems, considered as a kind of engineering object and developed in accordance with principles and generally accepted practices of system engineering.

\section{CONSTRUCTION OF FUNCTIONAL ARCHITECTURE OF THE CLASSIFIERS}

System design begins with a functional analysis of system in question (Architecture Framework, 2015). Since the classifier of system problems should reflect the entire set of problems that arise or may arise as a result of deviation from systemic principles in design or analysis of complex systems, functions of the classifier top level should describe all possible violations of such a process. The structure of functions of a complex system is quite transparent - problems in the system can arise both inside it and on the border between it and its environment (Architecture Framework, 2015). Therefore, this structure is divided into two subgroups, each of which should functionally be similar to the other, since when moving to a higher level of consideration, the previous system becomes a subsystem, and the problems of the external environment become intra-system problems. The opposite happens when moving to a lower level of consideration. Therefore, the structure of problems detected at the system level should also be displayed in the system, which includes the object/process in question, that is, on the interface between it and the external environment.

All problems in a simulated/designed object/process can logically be divided into a lack of systemicity in it, contradictions between its subsystems and excess of required resources of at least one of its subsystems over available ones. The same with the obvious changes caused by the transition of potential problems consideration to a higher level takes place on the interface between it and the external environment. Therefore, after the first attempts to analyze systemic problems (Lobanovsky Yu. I., 2018a), the following functional structure emerges, the purpose of which is to classify systemic problems:

Actions leading to intra-system problems

- Modeling/designing an object/process not as a system, but as a set of unconnected or weakly interconnected components.

- Modeling/designing a system, functioning of which leads to internal conflicts that are insoluble within the frames of system.

- Modeling/designing a system, functioning of subsystems of which leads to their resource deadlock.

\section{Actions leading to environmental problems}

- Modeling/designing a system interface as a set of random, uncontrolled or incorrectly defined relationships with the environment. 
- Modeling/designing a system interface, functioning of which leads to insoluble contradictions between the system and the environment.

- Modeling/designing a system interface, functioning of which leads to its resource deadlock.

Herewith, from the condition of similarity of functional structures at the level of the system and at the level of its environment, some functional element arose (third in the first section), which is absent in paper (Lobanovsky Yu. I., 2018a).

\section{VALIDATION OF REQUIREMENTS}

In accordance with the adopted system design process, we will proceed to the requirements analysis. Let's start with their validation - we need to make sure that (1) a set of requirements is correct, complete and consistent, (2) a sample can be created that meets the requirements and (3) a real solution that meets the requirements can be achieved and tested (Bahill A. T. et al., 2005). Since the general classifier of problems is a structured information object, where information is accumulated, stored and analyzed, the set of requirements for it, in general, should coincide with the requirements for any scientific theory, to which we should add the above-mentioned requirement for similarity of its elements in two neighboring levels. Therefore, the general classifier of systemic problems should be:

- Not contradictory (primarily internally).

- Complete (cover all possible systemic problems).

- Correct (display significantly different causes of systemic problems in various structural elements).

- Number of structural elements at levels of system and environment should be the same.

Property of non-contradictory of this classifier follows from its functional structure - it is obvious that the functions from the proposed set do not intersect. It is also clear that within the framework of the proposed structure, any problem can be accommodated, therefore the classifier is complete. However, its correctness, that is, the correspondence of its structure to real problems arising in the modeling/design of systems, can only be analyzed when these problems are placed in the structures of the classifier. The last requirement in the proposed structure is obviously fulfilled.

\section{SYNTHESIS OF THE SYSTEM}

In accordance with empirical rule of system engineering, which follows from the characteristics of psychophysiological capabilities of a person: "It is advisable to have $7 \pm 2$ structural units at one structural level of the classifier", when constructing the logical architecture, we will place all structural elements on the same level. Then there will be 6 units, and they will be top level of the classifier of system 
problems. In this work, we will restrict ourselves to this level. Further deepening of its structure can be carried out if such a need will arise further.

From the set of classifier functions and the conditions formulated in the previous paragraph, the following logical structure of the general classifier of system problems arises:

a) Non-systemicity (lack of a systemic approach) - uncontrolled, and therefore the adverse effect of the object/process components on their functioning (internal chaos).

b) Negative emergence - unknown or not taken into account by designers/researchers due to complexity of analysis the adverse interaction of subsystems/components of system in question, leading to its destruction.

c) Internal resource deadlock - the limitation of capabilities of at least one of the subsystems (its characteristics do not meet the requirements of the system), and this limitation cannot be overcome within this subsystem.

d) Non-systemicity at the supersystem level - the adverse effect of factors of the existing environment on the system functioning (adverse system interface).

e) Script change - unpredictable, unfavorable and previously non-existent influence of factors of changed environment on the system functioning (adverse interface change).

f) External resource deadlock - limitations of the system's capabilities within the framework of the supersystem (the same as the boundaries of development or limits of growth).

\section{VERIFICATION OF THE REQUIREMENTS}

To prove the correctness and completeness of the classifier structure, we consider 60 technical projects, natural and social processes that failed, 7 of which were considered in paper (Lobanovsky Yu. I., 2018a). In addition, 23 "famous failures" were taken from article (Bahill A. T. et al., 2005) (considered from a different point of view) and 4 more were selected from the book (Diamond J., 2005) as the brightest. And 26 remaining ones were taken almost randomly from an endless list of failures known in history; so that each of 6 classification sections had 10 examples (see Lobanovsky Yu. I., 2018b). It is assumed that such a quantity is sufficient for the final verification of requirements, provided that no examples are found that could not be placed in the structure of the general classifier of system problems.

For compactness of analysis of the results' presentation, we have used a tabular form. An event, process, or phenomenon that culminates in an incident, accident, or even disaster is described in the first column of the tables. The second column indicates the year of the incident or the approximate time boundaries of the process. In the third column there is a briefly description the reason for what happened and link to the source, which can be used to study this event in more detail, or to paper, where full list of 
links is given. It is assumed that the causes of all incidents from each table fit into the classifier section named in its heading.

First, we examine the section of the classifier a) "Non-systemicity (lack of a systemic approach) uncontrolled, and therefore the adverse effect of the object/process components on their functioning (internal chaos)". 
Table 1 - Internal non-systemicity

\begin{tabular}{|c|c|c|}
\hline Event/process/phenomenon & Year/Years & Cause \\
\hline Death of Titanic & 1912 & $\begin{array}{l}\text { Use of rivets losing strength in the cold, with which were secured the } \\
\text { outer sheets of ship's hull, what led to formation of unacceptably large } \\
\text { holes in it after a glancing blow of Titanic on an iceberg (Bahill A. T. et } \\
\text { al., 2005). }\end{array}$ \\
\hline $\begin{array}{l}\text { Closing of Soviet Lunar } \\
\text { Program }\end{array}$ & $1962-1974$ & $\begin{array}{l}\text { The development of the subsystems of lunar launch vehicle as a whole, } \\
\text { not at ground stands, but through its "shooting", which did not allow to } \\
\text { bring this system to operational state (Lobanovsky Yu. I., 2018a). }\end{array}$ \\
\hline Accident at Apollo 13 & 1970 & $\begin{array}{l}\text { Changing parameters of oxygen tank heater without a corresponding } \\
\text { change in its documentation (Bahill A. T. et al., 2005). }\end{array}$ \\
\hline $\begin{array}{l}\text { Challenger Space Shuttle } \\
\text { explosion }\end{array}$ & 1986 & $\begin{array}{l}\text { The erroneous design of sections joints of solid propellant boosters } \\
\text { assembled at the launch site, which did not ensure the tightness of the } \\
\text { connections, especially in the cold (Bahill A. T. et al., 2005; Lobanovsky } \\
\text { Yu. I., 2018b). }\end{array}$ \\
\hline $\begin{array}{l}\text { Ariane } 5 \text { launch vehicle } \\
\text { explosion }\end{array}$ & 1996 & $\begin{array}{l}\text { Using software of the previous model without processing and } \\
\text { verification (Bahill A. T. et al., 2005). }\end{array}$ \\
\hline Crash of Mars Climate Orbiter & 1999 & $\begin{array}{l}\text { Use of different units of measurement by manufacturer of Mars Climate } \\
\text { Orbiter and organization that controlled it (Bahill A. T. et al., 2005). }\end{array}$ \\
\hline Crash of Mars Polar Lander & 1999 & $\begin{array}{l}\text { There were no propulsion system tests of Mars Polar Lander in its } \\
\text { landing configuration (Bahill A. T. et al., 2005). }\end{array}$ \\
\hline $\begin{array}{l}\text { Redesign of A-380 Airbus } \\
\text { electrical system }\end{array}$ & $2000-2006$ & $\begin{array}{l}\text { Use of different versions of CATIA computer-aided design system that } \\
\text { were incompatible with each other in different divisions of Airbus } \\
\text { (Lobanovsky Yu. I., 2018b). }\end{array}$ \\
\hline $\begin{array}{l}\text { Closing of Lunar NASA's } \\
\text { Constellation Program }\end{array}$ & $2004-2010$ & $\begin{array}{l}\text { A deliberate violation of systemic principles in development of launch } \\
\text { vehicles in order to save money (Lobanovsky Yu. I., 2018b). }\end{array}$ \\
\hline $\begin{array}{l}\text { Determination of Chelyabinsk } \\
\text { meteoroid explosion energy }\end{array}$ & $2013-2016$ & $\begin{array}{l}\text { Inability to assess the parameters of this phenomenon that goes far } \\
\text { beyond the usual, and then direct manipulations for "face conservation" } \\
\text { (O. P. Popova et al., 2013; Brown P. G. et al., 2013; Lobanovsky Yu. I., } \\
\text { 2019) }\end{array}$ \\
\hline
\end{tabular}

It seems that all the incidents to which led non-systemic approach are quite understandable even with such a brief description. The only thing the author wanted to note is that despite the development of system engineering, major failures associated with non-systemic developments do not stop, and it even seems that their frequency over the past decades has not decreased.

Now we turn to the section of the classifier b) "Negative emergence - unknown or not taken into account by designers/researchers due to complexity of analysis the adverse interaction of subsystems/components of system in question, leading to its destruction".

Table 2 - Negative emergence

\begin{tabular}{|l|c|l|}
\hline Event/process/phenomenon & Year/Years & \multicolumn{1}{c|}{ Cause } \\
\hline $\begin{array}{l}\text { Salinization of Tigris and } \\
\text { Euphrates Interfluve }\end{array}$ & $560 \mathrm{~s} \mathrm{BC}$ & $\begin{array}{l}\text { Use of land reclamation methods suitable in Egypt, but unsuitable in } \\
\text { Mesopotamia (Lobanovsky Yu. I., 2018b). }\end{array}$ \\
\hline $\begin{array}{l}\text { Introduction of Christianity } \\
\text { in Kievan Rus and } \\
\text { undermining of its exports }\end{array}$ & 988 & $\begin{array}{l}\text { The cessation of annual trips of Kievan princes to surrounding } \\
\text { territories to collect the most important Russian export product - } \\
\text { Slavic slaves because of the difficulties in selling Christians to their } \\
\text { fellow believers from Byzantium (Lobanovsk Yu. I., 2018b). }\end{array}$ \\
\hline Airplane wing flutter & $1930-1945$ & $\begin{array}{l}\text { Destructive self-oscillations of aircraft wings due to positive } \\
\text { feedback between their aerodynamic and inertial characteristics } \\
\text { (Lobanovsky Yu. I., 2018b). }\end{array}$ \\
\hline
\end{tabular}




\begin{tabular}{|l|c|l|}
\hline Rocket engines explosions & $1930-1985$ & $\begin{array}{l}\text { Appearance of high-frequency self-oscillations in combustion } \\
\text { chambers of liquid rocket engines in the process of fuel combustion } \\
\text { (Lobanovsky Yu. I., 2018b). }\end{array}$ \\
\hline $\begin{array}{l}\text { Shimmy of aircraft nose } \\
\text { wheel }\end{array}$ & $1939-1945$ & $\begin{array}{l}\text { Self-oscillations of self-orienting nose wheel of the aircraft due to } \\
\text { the occurrence of positive feedback between its supporting and } \\
\text { inertial characteristics (Lobanovsky Yu. I., 2018b). }\end{array}$ \\
\hline $\begin{array}{l}\text { Tacoma Narrows Bridge } \\
\text { destruction }\end{array}$ & 1940 & $\begin{array}{l}\text { Destructive flexural-torsion self-oscillations of Tacoma suspension } \\
\text { bridge due to the occurrence of positive feedback between its inertial } \\
\text { and wind characteristics (Bahill A. T. et al., 2005; Lobanovsky Yu. } \\
\text { I., 2018b). }\end{array}$ \\
\hline $\begin{array}{l}\text { Pulling at a dive at transonic } \\
\text { speeds }\end{array}$ & $1943-1947$ & $\begin{array}{l}\text { Shift of focus of the aircraft wing back when approaching the speed } \\
\text { of flight to the speed of sound (Lobanovsky Yu. I., 2018b). }\end{array}$ \\
\hline $\begin{array}{l}\text { Launch vehicles redesigning } \\
\text { to reduce their sizes }\end{array}$ & $1960-2017$ & $\begin{array}{l}\text { Limitation of the size of giant launch vehicles due to rapid and } \\
\text { nonlinear increase in acoustic loads with increasing scales } \\
\text { (Lobanovsky Yu. I., 2018b). }\end{array}$ \\
\hline Chernobyl Disaster & $\begin{array}{l}\text { Steam explosion of a nuclear reactor due to positive reactivity of its } \\
\text { core during boiling of water coolant (Bahill A. T. et al., 2005; } \\
\text { Lobanovsky Yu. I., 2018b). }\end{array}$ \\
\hline Disaster on Yenisei & $\begin{array}{l}\text { Destructive self-oscillations in penstock/turbine system of Sayano- } \\
\text { Shushenskaya hydroelectric station due to the occurrence of positive } \\
\text { feedback between its hydrodynamic and energy characteristics } \\
\text { (Lobanovky Yu. I., 2018a). }\end{array}$ \\
\hline
\end{tabular}

In the case of negative emergence, one cannot usually blame of developers of the failed system, since disasters of this type are associated with processes that were unknown to them. And some theoretical or at least empirical understanding of these processes arises after conducting research work initiated precisely by these catastrophes. After that, similar reasons for possible future incidents should be transferred from the "Negative Emergence" to the "Non-systemicity" section, and in this case, developers should be fully responsible for their incompetence.

Consider section c) "Internal resource deadlock - the limitation of the capabilities of at least one of the subsystems (its characteristics do not meet the requirements of the system), and this limitation cannot be overcome within this subsystem". This section of the classifier was revealed only with a fullfledged systemic approach to the structuring of system problems and did not appear in any way during an empirical examination of the problems. However, after highlighting this section of the classifier, the planned 10 examples for filling were found easily.

Table 3 - Internal resource deadlock

\begin{tabular}{|l|c|l|}
\hline \multicolumn{1}{|c|}{ Event/process/phenomenon } & Year/Years & \multicolumn{1}{c|}{ Cause } \\
\hline $\begin{array}{l}\text { Failure with Nazi nuclear } \\
\text { bomb }\end{array}$ & $1939-1945$ & $\begin{array}{l}\text { Use only of heavy water as a neutron moderator (which was not available } \\
\text { in Germany in the required amounts) due to Bothe's error during his } \\
\text { experiments with graphite contaminated with boron, which is a strong } \\
\text { neutron absorber (Lobanovsky Yu. I., 2018b). }\end{array}$ \\
\hline $\begin{array}{l}\text { Inability of use of Ivy Mike } \\
\text { first thermonuclear device as } \\
\text { weapon }\end{array}$ & 1952 & $\begin{array}{l}\text { The impossibility of combat use of this device was caused by application } \\
\text { of deuterium in liquid cryogenic form, but not in the form of a solid } \\
\text { compound with lithium, as in subsequent thermonuclear warheads } \\
\text { (Lobanovsky Yu. I., 2018b). }\end{array}$ \\
\hline
\end{tabular}




\begin{tabular}{|l|c|l|}
\hline $\begin{array}{l}\text { Explosions of launch vehicles } \\
\text { with a large number of } \\
\text { engines }\end{array}$ & $1969-1981$ & $\begin{array}{l}\text { A high probability of an accident at the start due to the lack of reliability } \\
\text { of rocket engines (Lobanovsky Yu. I., 2018a, 2018b). Problem has } \\
\text { resolved in 2018. }\end{array}$ \\
\hline $\begin{array}{l}\text { Failure of IBM's PCjr Project } \\
- \text { the predecessor of laptops }\end{array}$ & 1983 & $\begin{array}{l}\text { Keyboard size was too little (Bahill A. T. et al., 2005). The problem was } \\
\text { solved when creating modern laptops. }\end{array}$ \\
\hline $\begin{array}{l}\text { Closing of A-12 stealth } \\
\text { carrier-based attack aircraft } \\
\text { Program }\end{array}$ & $1983-1990$ & $\begin{array}{l}\text { The inability to create external forms that satisfy both aerodynamic and } \\
\text { stealth requirements. The impossibility of creating of coating resistant to } \\
\text { effects of sea water (Bahill A. T. et al., 2005, Lobanovsky Yu. I., 2018b). }\end{array}$ \\
\hline $\begin{array}{l}\text { Mass failure of GE } \\
\text { refrigerators with } \\
\text { turbochargers }\end{array}$ & 1986 & $\begin{array}{l}\text { The fragility of turbo compressor rotor, made by powder metallurgy with } \\
\text { the aim of to reduce costs (Bahill A. T. et al., 2005). }\end{array}$ \\
\hline $\begin{array}{l}\text { Renouncement from } \\
\text { ekranoplanes }\end{array}$ & 1991 & $\begin{array}{l}\text { The inability to create a wing which is at the same time narrow } \\
\text { (aerodynamically efficient) and wide (providing the necessary height for } \\
\text { flying with a screen effect over an uneven surface) (Lobanovsky Yu. I., } \\
\text { 2018b). }\end{array}$ \\
\hline Failure of Biosphere-2 Project & $1991-1994$ & $\begin{array}{l}\text { Uncontrolled reproduction of microorganisms, which led to a continuous } \\
\text { decrease in the oxygen content in Biosphere-2 complex and destruction } \\
\text { of its ecosystem (Lobanovsky Yu. I., 2018b). }\end{array}$ \\
\hline $\begin{array}{l}\text { Colombia Space Shuttle } \\
\text { disaster }\end{array}$ & 2002 & $\begin{array}{l}\text { Insufficient strength of foamed coating of external fuel tank, which led } \\
\text { to damage to leading edge of wing of this Space Shuttle and its death } \\
\text { upon returning to the Earth (Bahill A. T. et al., 2005; Lobanovsky Yu. } \\
\text { I., 2018b). }\end{array}$ \\
\hline $\begin{array}{l}\text { Abandonment of Ares-1 solid- } \\
\text { fuel manned launch vehicle }\end{array}$ & 2010 & $\begin{array}{l}\text { Unacceptably large vibrations for a manned launch vehicle during } \\
\text { operation of its solid rocket engine (Lobanovsky Yu. I., 2018b). }\end{array}$ \\
\hline
\end{tabular}

We proceed to the section of the classifier d) "Non-systemicity at the supersystem level - the adverse effect of factors of the existing environment on the system functioning (adverse system interface)".

Table 4 - Non-systemicity at supersystem level

\begin{tabular}{|l|c|l|}
\hline Event/process/phenomenon & Year/Years & \multicolumn{1}{|c|}{ Cause } \\
\hline Soviet pre-war fighters & $1939-1941$ & $\begin{array}{l}\text { Misconceptions about nature of hostilities in the future air war, which } \\
\text { led to inadequate structure of fighter aircraft at its beginning } \\
\text { (Lobanovsky Yu. I., 2018a). }\end{array}$ \\
\hline $\begin{array}{l}\text { Su-2 lightweight single-engine } \\
\text { bomber }\end{array}$ & 1941 & $\begin{array}{l}\text { The impossibility of effective action under the dominance of enemy } \\
\text { aircrafts in the air, which led to the rapid cessation of its production } \\
\text { (Lobanovsky Yu. I., 2018b). }\end{array}$ \\
\hline V-2 ballistic missile & $1938-1945$ & $\begin{array}{l}\text { Outlays on its development, creation and combat use of resources that } \\
\text { could were used to produce significantly more effective types of } \\
\text { weapons in a war (Lobanovsky Yu. I., 2018b). }\end{array}$ \\
\hline Ford Edsel commercial failure & $1957-1959$ & $\begin{array}{l}\text { Eight-year (from 1948 to 1956) Ford's development of a prestigious } \\
\text { mass middle-class car, which led to the creation of a "gas eater" that was } \\
\text { not in demand on the market (Bahill A. T. et al., 2005). }\end{array}$ \\
\hline Aswan Dam and Lake Nasser & $1960-1970$ & $\begin{array}{l}\text { Aswan Dam, forming Lake Nasser, blocked the annual inflow of fertile } \\
\text { silt from the upper reaches of the river to its delta, which leads to the } \\
\text { gradual destruction of Nile Delta - the breadbasket of Egypt, and also } \\
\text { requires the constant use of chemical fertilizers, for which needs electric } \\
\text { energy generated by the Aswan Hydroelectric Power Station, or external } \\
\text { deliveries of fertilizers (Lobanovsky Yu. I., 2018b). }\end{array}$ \\
\hline Vietnam War & $1965-1972$ & $\begin{array}{l}\text { American society has demonstrated clearly a reluctance to bear such } \\
\text { hardships that were considered quite acceptable only recently during the } \\
\text { Korean War (1950 - 1953) (Bahill A. T. et al., 2005; Lobanovsky Yu. } \\
\text { I., 2018b) }\end{array}$ \\
\hline
\end{tabular}




\begin{tabular}{|l|c|l|}
\hline $\begin{array}{l}\text { Commercial failure of Coca } \\
\text { Cola's New Coke }\end{array}$ & 1988 & $\begin{array}{l}\text { Coca Cola's attempt to expand its beverage sales market by mimicking } \\
\text { the taste of Pepsi Cola's popular drink led to a rapid flow of customers } \\
\text { to a competitor (Bahill A. T. et al., 2005).. }\end{array}$ \\
\hline $\begin{array}{l}\text { Failure of UNIFOR mission in } \\
\text { Bosnia }\end{array}$ & $1992-1995$ & $\begin{array}{l}\text { The United Nations forces for protection of Bosnia civilian population, } \\
\text { with all their training, were insufficient quantitatively to effectively } \\
\text { counter local armed forces (Bahill A. T. et al., 2005). }\end{array}$ \\
\hline $\begin{array}{l}\text { Iridium satellite } \\
\text { communications system } \\
\text { commercial failure }\end{array}$ & 1999 & $\begin{array}{l}\text { Motorola's use of an analog system for satellite telephony in the context } \\
\text { of rapid development of more promising digital systems led to the failure } \\
\text { of this program (Bahill A. T. et al., 2005). }\end{array}$ \\
\hline $\begin{array}{l}\text { Loss of market by A-380 } \\
\text { Airbus }\end{array}$ & $\begin{array}{l}\text { no05-until } \\
\text { now }\end{array}$ & $\begin{array}{l}\text { Airbus's misconceptions about transcontinental passenger } \\
\text { transportation through airport hubs as the best way to organize them } \\
\text { (Lobanovsky Yu. I., 2018b). }\end{array}$ \\
\hline
\end{tabular}

It can be noted here that, despite the development of system engineering in recent decades, errors related to non-systemic developments both at the system level and at the supersystem level do not stop, and they are committed constantly even by leaders in the system engineering - NASA and Airbus.

We consider now the section of the classifier e) "Script change - the unpredictable, unfavorable and previously non-existent influence of factors of the changed environment on the system functioning (adverse interface change)". In a certain sense, it is analogue of the section b) "Negative emergence"; only here unfavorable and unpredictable connections arise already between systems. That is, when moving to a higher level of consideration, section e) simply goes to section b).

Table 5 - Script change

\begin{tabular}{|c|c|c|}
\hline Event/process/phenomenon & Year/Years & Cause \\
\hline Macedonian phalanx & $350-168 \mathrm{BC}$ & $\begin{array}{l}\text { The helplessness of a closed phalanx formation on rough terrain } \\
\text { against the more flexible, disjointed-closed formation of the Roman } \\
\text { legion (Lobanovsky Yu. I., 2018a). }\end{array}$ \\
\hline $\begin{array}{l}\text { Viking settlements in } \\
\text { Greenland }\end{array}$ & $984-1435$ & $\begin{array}{l}\text { Little Ice Age, which led to a sharp deterioration in life in Greenland, } \\
\text { isolation from Europe and the death of the Viking colony (Diamond J., } \\
\text { 2005). }\end{array}$ \\
\hline Dreadnought battleships & $1906-1941$ & $\begin{array}{l}\text { The impotence of guns and armor of battleships against carrier-based } \\
\text { aircrafts (Lobanovsky Yu. I., 2018a). }\end{array}$ \\
\hline Zero fighter & $1942-1944$ & $\begin{array}{l}\text { The dominance of Japanese carrier-based fighter Zero at the Pacific } \\
\text { theater of operations over any enemy in dog fights in } 1942 \text { and its } \\
\text { helplessness against the attacks of new American fighters on a dive } \\
\text { (boom-zoom) in } 1944 \text { (Lobanovsky Yu. I., 2018b). }\end{array}$ \\
\hline $\begin{array}{l}\text { Strategic supersonic cruise } \\
\text { missiles }\end{array}$ & $1950-1964$ & $\begin{array}{l}\text { Non-competitiveness of strategic supersonic cruise missiles after the } \\
\text { advent of intercontinental ballistic missiles and sea-based ballistic } \\
\text { missiles (Lobanovsky Yu. I., 2018b). }\end{array}$ \\
\hline $\begin{array}{l}\text { Concorde supersonic } \\
\text { passenger aircraft Program }\end{array}$ & $1976-2003$ & $\begin{array}{l}\text { Commercial use of Concorde aircraft proved to be excessively } \\
\text { expensive in the face of a sharp increase in fuel prices (Bahill A. T. et } \\
\text { al., 2005). }\end{array}$ \\
\hline Space Shuttle Program & $1981-2010$ & $\begin{array}{l}\text { The economic inefficiency of manned Space Shuttles because of a } \\
\text { sharp diminishing in the number of launches due to the complexity of } \\
\text { inter-flight service and the changing priorities of the American space } \\
\text { program (Lobanovsky Yu. I., 2018b). }\end{array}$ \\
\hline Crisis of world nuclear energy & $\begin{array}{c}1986-\text { until } \\
\text { now }\end{array}$ & $\begin{array}{l}\text { Changing of reliability criteria of nuclear energy blocks after the } \\
\text { Chernobyl Disaster, and increasing public attention to the environment } \\
\text { (Lobanovsky Yu. I., 2018b). }\end{array}$ \\
\hline
\end{tabular}




\begin{tabular}{|l|c|l|}
\hline $\begin{array}{l}\text { Attack of International Trade } \\
\text { Center in New York }\end{array}$ & 2001 & $\begin{array}{l}\text { The construction of the buildings was unable to withstand the terrorist } \\
\text { attack using large and almost completely refueled passenger aircraft } \\
\text { (Bahill A. T. et al., 2005). }\end{array}$ \\
\hline $\begin{array}{l}\text { Northeast American energy } \\
\text { collapse }\end{array}$ & 2003 & $\begin{array}{l}\text { Growth of trees near power lines, while operators were neglecting to } \\
\text { the optional standards for cleaning lines from stands, which was the } \\
\text { trigger for the collapse (Bahill A. T. et al., 2005). }\end{array}$ \\
\hline
\end{tabular}

It seems that the presented examples are quite self-evident. It would like to make only one remark: the Japanese fighter Zero has overcome the path from "absolute weapon - king of the air" to "turkey" the object of almost safe hunting, in a record short time - in about 2 years.

And finally, let's move on to the section of the classifier f) "External resource deadlock limitations of the system's capabilities within the framework of the supersystem (the same as the boundaries of development or limits of growth)".

Table 6 - External resource deadlock

\begin{tabular}{|c|c|c|}
\hline Event/process/phenomenon & Year/Years & Cause \\
\hline $\begin{array}{l}\text { Hunger and catastrophic decline } \\
\text { of population size on Easter } \\
\text { Island }\end{array}$ & $1400-1600$ & $\begin{array}{l}\text { Loss of food resources, primarily from the surrounding ocean due to } \\
\text { lack of boats, caused by death of forests, which went to the production } \\
\text { of ropes, rafters and sledges, necessary for construction of ritual } \\
\text { complexes in the form of giant statues - moai (Diamond J., 2005). }\end{array}$ \\
\hline $\begin{array}{l}\text { Exhaustion of the "genetic } \\
\text { resource" of Pitcairn Island } \\
\text { population }\end{array}$ & $1500-1700$ & $\begin{array}{l}\text { Isolation of the island, which led to the extinction of its small } \\
\text { population due to lack of "fresh blood" influx (Diamond J., 2005). }\end{array}$ \\
\hline Tulip fever, MMM and bitcoin & $1636-2018$ & $\begin{array}{l}\text { Collapse of growing financial pyramid when it reaches resource } \\
\text { boundaries (Lobanovsky Yu. I., 2018b). }\end{array}$ \\
\hline $\begin{array}{l}\text { Collapse of Russian campaign } \\
\text { of Napoleon }\end{array}$ & 1812 & $\begin{array}{l}\text { The inability to supply French army, which led to its almost complete } \\
\text { loss from cold and hunger, despite the French winning all the major } \\
\text { battles (Lobanovsky Yu. I., 2018b). }\end{array}$ \\
\hline $\begin{array}{l}\text { Results of the } 1941 \text { campaign } \\
\text { on Eastern Front }\end{array}$ & 19 & $\begin{array}{l}\text { Winter defeat of advancing German troops, caused by their depletion } \\
\text { due to lack of reserves, because of enemy underestimation and the } \\
\text { scattering of available resources (Lobanovsky Yu. I., 2018b). }\end{array}$ \\
\hline Cuban $n$ & 1962 & $\begin{array}{l}\text { Desire to quickly change the balance of power between the USSR and } \\
\text { the USA in the field of strategic weapons in the absence of real } \\
\text { economic opportunities for the USSR at that time (Lobanovsky Yu. I., } \\
\text { 2018b). }\end{array}$ \\
\hline Fifth generation fighters & $\begin{array}{l}1986-\text { until } \\
\text { now }\end{array}$ & $\begin{array}{l}\text { The impossibility due to the high cost of building a sufficient number } \\
\text { of such fighters to ensure all necessary operations (Lobanovsky Yu. I., } \\
\text { 2018a). }\end{array}$ \\
\hline Hubble Space Telescope & 1990 & $\begin{array}{l}\text { Lack of testing the system as a whole on Earth due to deficit in funding, } \\
\text { which led to the need to modernize the telescope in orbit in open space } \\
\text { (Bahill A. T. et al., 2005). }\end{array}$ \\
\hline Genocide in Rwanda & 1994 & $\begin{array}{l}\text { Extreme land shortages due to rapid population growth exacerbated by } \\
\text { the ethnic conflict of Hutu and Tutsi tribes (Diamond J., 2005). }\end{array}$ \\
\hline $\begin{array}{l}\text { Discontinuation of Super } \\
\text { Collider building }\end{array}$ & 1995 & $\begin{array}{l}\text { Cost overrun during the construction of Super Collider, which led to } \\
\text { loss of political support for the project, a further reduction in funding } \\
\text { and its complete halt (Bahill A. T. et al., 2005). }\end{array}$ \\
\hline
\end{tabular}

So far, there have been not too many examples of technical projects here, apparently due to the fact that truly large and complex systems of such kind began to be created relatively recently, except for the construction of large architectural structures such as megalithic dolmens, Egyptian pyramids or the 
Great Chinese Wall. But about those times, it seems, not enough is known to confidently classify such objects and their problems from a systemic point of view. However, most recently, technical systems of the highest technological level have begun to appear, which are increasingly beginning to experience external constraints, mainly for now, of a financial nature (Hubble Space Telescope, Super Collider, fifthgeneration fighters, James Webb Space Telescope).

\section{CONCLUSIONS}

1. Based on the systemic principles and requirements analysis, the upper level of the general classifier of system problems is built.

2. The classifier is consistent, complete and correct, which is confirmed by the placement in it of all considered objects or phenomena that led to incidents, accidents or disasters, as well as the fact that no problematic objects or phenomena were found that could not be placed in the classifier.

3. The classifier is applicable to systemic problems of a technical, environmental and sociopolitical nature.

4. The position of problem in the classifier depends on the level of science and technology at the time of development of this system. Over time, as knowledge accumulates, it is possible to transfer problems from more difficult levels for the developer to simpler (from non-acquaintance to chaos). That is, the taxonomy of the problems is relative and time-dependent. 


\section{BIBLIOGRAPHIC REFERENCES}

Architecture Framework 2.0, DOD (2015).

Bahill, A. T., Henderson S. J. (2005). Requirements, Development, Verification, and Validation Exhibited in Famous Failures. Wiley InterScience, Syst Eng 8: 1 - 14.

https://onlinelibrary.wiley.com/doi/abs/10.1002/sys.20017

Brown P. G. et al. (2013). A 500-kiloton airburst over Chelyabinsk and an enhanced hazard from small impactors. Nature Letter, vol. 503, no 7475.

http://www.nature.com/nature/journal/v503/n7475/full/nature12741.html

Diamond J. (2005). Collapse: How Societies Choose to Fail or Succeed. Viking Press, 592 pp. https://www.e-reading.club/book.php?book=1006586

Lobanovsky Yu. I. (2018a). Non-systemicity is a source of critical problems in the design of complex systems. Synerjetics Group: 1 - 14. http://www.synerjetics.ru/article/nonsystems.pdf (in Russian)

Lobanovsky Yu. I. (2018b). General classifier of system problems. Parts I - II. Russian Technological Journal, vol. 6, no 4: 5 - 25. https://rtj.mirea.ru/journal-archive/two-thousand-eighteen/volume-6-no-4/ (in Russian)

Lobanovsky Yu. I. (2019). The interface between science and culture: Script change. Synerjetics Group: 1 - 22. http://www.synerjetics.ru/article/script_change.pdf (in Russian)

Popova O. P. et al. (2013). Chelyabinsk Airburst, Damage Assessment, Meteorite Recovery, and Characterization. Science, vol. 342, no 6162. https://www.sciencemag.org/content/342/6162/1069 